\title{
THE RELATIONSHIP BETWEEN MACRO NUTRITION AND PHYSICAL ACTIVITIES WITH NUTRITION STATUS IN EMPLOYEE OFFICES OF THE POLTEKKES KEMENKES DIRECTORATE OF JAKARTA II
}

\author{
Novita Dewi, Isti Istianah \\ Jurusan Gizi Sekolah Tinggi Ilmu Kesehatan Binawan \\ J1. Kalibata Raya 25-30 Jakarta Timur 13630 \\ Email : tadew.novi@gmail.com
}

\begin{abstract}
Abstract: Nutritional status was an important element in determining someone health status. Nutrition status was good when nutritional intake balanced with the needs of the Body. Physical activity was a way to regulate the amount of energy entering and leaving in the body. The purpose of this study was to analyze the relationship between the macronutrient intake and physical activity with nutritional status at office staff of Directorate Poltekkes Kemenkes of Jakarta II. This research was conducted in April-May 2018 at the Office of Poltekkes Kemenkes Directorate of Jakarta II. The number of samples which was obtained was 49 people and Cross-sectional research design with a Chi-Square test. The data which was used was primary data. It mean the researcher took the data by conducting direct interview with using questionnaire. Most intake of more protein as many as 27 people $(55.1 \%)$, fat as many as 35 people (71.4\%), and carbohydrates as many as 29 people (59.2\%). More nutritional status as many as 32 people $(65.3 \%)$ and normal nutritional status of 17 people (34.7\%). While physical activity mostly has physical activity is as much as 34 people $(69.45 \%)$. There was a significant relationship between protein intake (p: 0.042), fat intake (p: 0.000), carbohydrate intake (p: 0.000) with nutritional status. There was a relationship between the intakes of macronutrients (protein, fat and carbohydrates) with nutritional status.
\end{abstract}

Keywords: physical activity, macronutrient intake, nutritional status.

\section{HUBUNGAN ASUPAN ZAT GIZI MAKRO DAN AKTIVITAS FISIK DENGAN STATUS GIZI PADA PEGAWAI KANTOR DIREKTORAT POLTEKKES KEMENKES JAKARTA II}

\begin{abstract}
ABSTRAK
Status gizi merupakan salah satu unsur penting dalam penentuan status kesehatan seseorang. Status gizi baik apabila asupan gizi sesuai dengan kebutuhan tubuh dan aktivitas fisik merupakan cara untuk mengatur jumlah energi yang masuk dan keluar dalam tubuh. Tujuan penelitian ini adalah untuk menganalisis hubungan antara asupan zat gizi makro dan aktivitas fisik dengan status gizi pada pegawai kantor Direktorat Poltekkes Kemenkes Jakarta II. Penelitian ini dilakukan pada bulan April-Mei 2018 di Kantor Direktorat Poltekkes Kemenkes Jakarta II. Dengan jumlah sampel diperoleh 49 orang. Desain penelitian Cross Sectional dengan uji Chi-Square. Data yang digunakan adalah data primer yaitu dengan melakukan wawancara langsung dengan menggunakan kuesioner. Sebagian besar asupan lebih protein sebanyak 27 orang $(55.1 \%)$, lemak sebanyak 35 orang $(71.4 \%)$, dan karbohidrat sebanyak 29 orang (59.2\%). Status gizi lebih sebanyak 32 orang (65.3\%) dan status gizi normal sebanyak 17 orang (34.7\%). Sedangkan untuk aktivitas fisik sebagian besar memilki aktivitas fisik sedang sebanyak 34 orang $(69.45 \%)$. Terdapat hubungan yang signifikan antara asupan protein (p:0.042), asupan lemak (p:0.000), asupan karbohidrat (p:0.000) dengan status gizi. Ada hubungan antara asupan zat gizi makro (protein, lemak dan karbohidrat) dengan status gizi.
\end{abstract}

Kata Kunci: aktivitas fisik, asupan zat gizi makro, status gizi. 


\section{PENDAHULUAN}

Indonesia saat ini sedang mengalami masalah gizi ganda, dimana masalah gizi kurang yang belum sepenuhnya terealisasikan namun sudah muncul masalah gizi lebih atau obese (1). Status gizi merupakan salah satu unsur penting dalam penentuan status kesehatan. Seseorang akan mempunyai status gizi baik apabila asupan gizi sesuai dengan kebutuhan tubuh. Asupan gizi yang kurang dalam makanan dapat menyebabkan kasus kekurangan gizi, sebaliknya orang yang asupan gizinya berlebih akan menderita gizi lebih (2).

Berdasarkan hasil Riset Kesehatan Dasar tahun 2013, prevalensi penduduk dewasa dengan berat badan lebih sebanyak 13,5\%. Prevalensi obesitas penduduk laki-laki dewasa pada tahun 2013 sebanyak 19,7\%, lebih tinggi dari tahun $2007(13,9 \%)$ dan tahun 2010 (7,8\%). Pada tahun 2013, prevalensi obesitas perempuan dewasa ( $>18$ tahun) $32,9 \%$, naik $18,1 \%$ dari tahun 2007 $(13,9 \%)$ dan $17,5 \%$ dari tahun 2010 $(15,5 \%)$. Sedangkan hasil penelitian yang dilakukan oleh (3) menunjukkan bahwa prevalensi obesitas PNS Sekretariat Jenderal Kementrian
Kesehatan RI sekitar 48\%. Pada penelitian tersebut memperlihatkan adanya hubungan yang bermakna antara aktivitas fisik dan stres serta usia dengan kejadian obesitas.

Hasil penelitian yang dilakukan oleh (4) menunjukkan bahwa pegawai Poltekkes Kemenkes Jakarta II dengan IMT gemuk lebih banyak dibandingkan dengan IMT normal, responden dengan IMT normal sebanyak 45\% (33 orang) dan gemuk 55\% (41 orang).

Aktivitas fisik secara teratur bermanfaat untuk mengatur berat badan serta mengutakan sistem jantung dan pembuluh darah. Terdapat 22 provinsi dengan penduduk aktivitas fisik tergolong kurang aktif, salah satunya adalah provinsi penduduk DKI Jakarta sebanyak 44,2\%. (1)

Asupan gizi melalui konsumsi makanan dan aktivitas fisik merupakan cara untuk mengatur jumlah energi yang masuk dan keluar dalam tubuh. Berdasarkan penelitian yang dilakukan oleh (5) menunjukkan bahwa 100\% responden dengan aktivitas fisik ringan memiliki status gizi lebih. 23 orang $(56,1 \%)$ dengan asupan protein $>70 \%$ dari AKG memiliki status gizi lebih dan 
sebanyak 20 orang $(87 \%)$ dengan asupan lemak lebih memiliki status gizi lebih.

\section{METODE PENELITIAN}

Penelitian ini merupakan penelitian deskriptif analitik dengan pendekatan cross sectional (potong lintang) dan dilaksanakan di wilayah kerja kantor Direktorat Poltekkes Kemenkes Jakarta II, yaitu bulan Mei 2018. Variable bebas yang diteliti yaitu asupan zat gizi makro (karbohidrat, protein, lemak) dan aktivitas fisik sedangkan variable terikatnya adalah status gizi. Populasi dalam penelitian ini adalah seluruh pegawai kantor Direktorat Poltekkes Kemenkes Jakarta II yang berstatus pegawai negeri sipil dan pegawai honorer. Jumlah sampel yang memenuhi criteria penelitian yaitu sebanyak 49 orang. Pengambilan sampel dilakukan dengan teknik purposive sampling. Untuk penelitian ini diambil sampel yang berusia 25-60 tahun.

Pengumpulan data dilakukan melalui pengumpulan data primer yang diperoleh melalui pengukuran tinggi badan, penimbangan berat badan, asupan karbohidrat, lemak, protein melalui recall $2 \times 24$ jam (hari kerja dan hari libur) serta tingkat aktivitas dan data sekunder yang berupa jumlah populasi pegawai kantor Direktorat Poltekkes Kemenkes Jakarta II. Pengukuran berat badan dan tinggi badan masing-masing responden dilakukan untuk menentukan Indeks Massa Tubuh (IMT), yang kemudian dikategorikan dalam kelompok normal (IMT> $25 \mathrm{~kg} / \mathrm{m}^{2}$ ) dan normal (IMT 18.5 $-25 \mathrm{~kg} / \mathrm{m}^{2}$ ).

Pengambilan data asupan zat gizi makro yaitu karbohidrat, protein dan lemak yang dikonsumsi oleh para responden perhari dilakukan menggunakan metode recall 2x24 jam. Data ini kemudian diolah menggunakan program nutrisuvey untuk mengetahui jumlah asupan zat gizi makro yang dikonsumsi responden. Dan untuk pengambilan data aktivitas fisik dilakukan wawancara dengan menggunakan kuesioner.

Analisa data hasil penelitian diolah menggunakan program SPSS dengan uji statistik Chi-Square yaitu untuk analisis statistik mengetahui hubungan atau membuktikan hipotesa 
dengan variabel dependen dan independen berskala ordinal atau pengkategorian pada statistik non parametrik dengan tanpa memperhatikan normalitas distribusi.

\section{HASIL DAN PEMBAHASAN}

Jumlah sampel pada penelitian ini adalah 49 orang dengan rentang usia dari 25 sampai 60 tahun yang merupakan pegawai PNS dan honorer kantor Direktorat Poltekkes Kemenkes Jakarta II. Berdasarkan hasil yang ada, untuk distribusi menurut kelompok umur terdapat 31 responden $(63.3 \%)$ dengan umur dari 30 sampai 49 tahun. Untuk jenis kelamin sebagian besar responden yaitu 26 orang (53.1\%) berjenis kelamin perempuan. Tabel 1

Berdasarkan penelitian, diperoleh hasil seperti yang disajikan dalam Tabel 2 sebelumnya, ada 27 orang (55.1\%) memiliki asupan protein lebih dari AKG, sebanyak 35 orang (71.4\%) memiliki asupan lemak lebih dan sebanyak 29 orang (59.2\%) memilki asupan lebih dari AKG. Sedangkan 22 orang $(44.9 \%)$ memiliki asupan protein cukup, 14 orang (28.6\%) memiliki asupan lemak cukup dan 20 orang (40.8\%) memiliki asupan karbohidrat cukup.

Berdasarkan hasil pengamatan jenis lemak yang sering dikonsumsi adalah lemak jenuh seperti gorengan, telur yang digoreng, daging kambing dan jeroan. Untuk lemak tidak jenuh jenis makanan yang dikonsumsi adalah alpukat. Sedangkan yang memiliki asupan karbohidrat lebih, sebagian besar subjek penelitian mengkonsumsi sumber karbohidrat kompleks seperti nasi, mie, roti, umbi-umbian dan pasta. Untuk sumber karbohidrat sederhana yang dikonsumsi subjek penelitian adalah gula pasir, minuman kemasan dan susu kental manis.

Tabel 1. Distribusi Responden Kelompok Umur dan Jenis Kelamin

\begin{tabular}{lcc}
\hline $\begin{array}{c}\text { Karakteristik } \\
\text { Subjek Penelitian }\end{array}$ & $\begin{array}{c}\text { Frekuensi } \\
\text { (orang) }\end{array}$ & $\%$ \\
\hline $\begin{array}{l}\text { Kelompok Umur } \\
\text { (tahun) }\end{array}$ & 3 & 6.1 \\
$25-29$ & 31 & 63.3 \\
$30-49$ & 15 & 30.6 \\
$50-60$ & & \\
\hline Jenis Kelamin & & \\
$\quad$ Laki-laki & 23 & 46.9 \\
$\quad$ Perempuan & 26 & 53.1 \\
\hline
\end{tabular}


Tabel 2. Distribusi Frekuensi Responden berdasarkan Asupan Protein, Lemak dan Karbohidrat

\begin{tabular}{lcc}
\hline Asupan Zat Gizi & $\begin{array}{c}\text { Frekuensi } \\
\text { (orang) }\end{array}$ & $\begin{array}{c}\text { Persentase } \\
(\%)\end{array}$ \\
\hline Kecukupan Protein & & \\
Cukup (80 - 100\% & 22 & 44.9 \\
AKG) & 27 & 55.1 \\
Lebih (>100\% AKG) & & \\
\hline Kecukupan Lemak & 14 & 28.6 \\
Cukup (80 - 100\% & 35 & 71.4 \\
AKG) & & \\
Lebih (>100\% AKG) & 20 & 40.8 \\
\hline Kecukupan Karbohidrat & 29 & 59.2 \\
Cukup (80 - 100\% & & \\
AKG) & & \\
Lebih (>100\% AKG) &
\end{tabular}

Dari penelitian Tabel 3 diperoleh ada 34 orang (69.4\%) memilki aktivitas fisik sedang dan 15 orang (30.6\%) memiliki aktivitas fisik berat. Berdasarkan hasil penelitian diperoleh data bahwa lebih banyak subjek penelitian yang memiliki status gizi lebih dengan IMT > $25 \mathrm{~kg} / \mathrm{m}^{2}$ yaitu 32 orang $(65.3 \%)$ dab 17 orang $(34.7 \%)$ yang normal dengan IMT 18.5-25 $\mathrm{kg} / \mathrm{m}^{2}$.

Status gizi lebih merupakan terjadinya berbagai penyakit dan gangguan pada tubuh. Seseorang yang menderita gizi lebih berisiko tinggi mengalami penyakit jantung, tekanan darah tinggi dan kolesterol darah tinggi. Selian itu gizi lebih juga meningkatkan risiko terhadap penyakit osteoartritis, penyakit sendi tulang, berkurangnya kelenturan dan gangguan gerakan, atau

Tabel 3. Distribusi Frekuensi Kriteria Responden

\begin{tabular}{lll}
\hline $\begin{array}{l}\text { Kriteria } \\
\text { Responden }\end{array}$ & $\begin{array}{l}\text { Frekuensi } \\
\text { (orang) }\end{array}$ & $\begin{array}{l}\text { Persentase } \\
(\%)\end{array}$ \\
\hline Aktivitas Fisik & & \\
$\quad$ Sedang & 34 & 69.4 \\
Berat & 15 & 30.6 \\
$\quad$ Jumlah & 49 & 100 \\
Status Gizi & & \\
$\quad$ Normal & 17 & 34.7 \\
Lebih & 32 & 65.3 \\
Jumlah & 49 & 100 \\
\hline
\end{tabular}


berkurangnya mobilitas. Karena susah melakukan gerakan fisik, orang dengan gizi lebih cenderung melakukan aktivitas ringan, sehingga berat badan susah turun yang selanjutnya berkontribusi terhadap proses degeneratif. Gizi lebih juga merupakan faktor bermakna dalam perkembangan penyakit diabetes melitus tidak tergantung insulin, karena sekresi insulin dalam bentuk yang tidak tepat atau resistensi sel lemak yang membesar terhadap aktivitas insulin. (6) Hasil penelitian yang dilakukan pada pegawai kantor Direktorat Poltekkes Kemenkes Jakarta II ditunjukkan pada Tabel 4, bahwa ada hubungan antara asupan protein dengan status gizi $(\mathrm{p}=0.042)$. Hasil penelitian ini juga menunjukkan bahwa ada hubungan antara asupan lemak dengan status gizi $(\mathrm{p}=0.000)$, dan untuk

Tabel 4. Uji statistik status Gizi

\begin{tabular}{|c|c|c|c|c|c|c|c|}
\hline \multirow{3}{*}{ Status } & \multicolumn{6}{|c|}{ Status Gizi } & \multirow[t]{3}{*}{ P value } \\
\hline & \multicolumn{2}{|c|}{ Normal } & \multicolumn{2}{|c|}{ Lebih } & \multicolumn{2}{|c|}{ Total } & \\
\hline & $\mathrm{N}$ & $\%$ & $\mathrm{~N}$ & $\%$ & $\mathrm{~N}$ & $\%$ & \\
\hline \multicolumn{8}{|c|}{ Asupan Protein } \\
\hline Cukup & 11 & 50.0 & 11 & 50.0 & 22 & 100 & \multirow[t]{3}{*}{0.042} \\
\hline Lebih & 6 & 22.2 & 21 & 77.8 & 27 & 100 & \\
\hline Jumlah & 17 & 34.7 & 32 & 65.3 & 49 & 100 & \\
\hline \multicolumn{8}{|c|}{ Asupan Lemak } \\
\hline Cukup & 13 & 92.9 & 1 & 7.1 & 14 & 100 & \multirow{3}{*}{0.000} \\
\hline Lebih & 4 & 11.4 & 31 & 88.6 & 35 & 100 & \\
\hline Jumlah & 17 & 34.7 & 32 & 65.3 & 49 & 100 & \\
\hline \multicolumn{8}{|c|}{ Asupan Karbohidrat } \\
\hline Cukup & 17 & 85.0 & 3 & 15.0 & 20 & 100 & \multirow{3}{*}{0.000} \\
\hline Lebih & 0 & 0 & 29 & 100 & 29 & 100 & \\
\hline Jumlah & 17 & 34.7 & 32 & 65.3 & 49 & 100 & \\
\hline \multicolumn{8}{|c|}{ Aktivitas Fisik } \\
\hline Sedang & 12 & 35.3 & 22 & 64.7 & 34 & 100 & \multirow{3}{*}{0.894} \\
\hline Berat & 5 & 33.3 & 10 & 66.7 & 15 & 100 & \\
\hline Jumlah & 17 & 34.7 & 32 & 65.3 & 49 & 100 & \\
\hline
\end{tabular}


hubungan asupan karbohidrat dengan status gizi juga menunjukkan ada hubungan yang bermakna $(\mathrm{p}=0.000)$.

Hal ini tidak sejalan dengan hasil penelitian Stephanie et al (2013), bahwa tidak terdapat hubungan antara asupan protein dengan status gizi (p:0.602). (7) Sebagai zat pembangun, protein merupakan bahan pembentuk jaringanjaringan baru yang selalu terjadi dalam tubuh. Fungsi utama protein bagi tubuh ialah untuk membentuk jaringan baru da mempertahankan jaringan yang telah ada. Protein dapat juga digunakan sebagai bahan bakar apabila keperluan energi tubuh tidak terpenuhi oleh karbohidrat dan lemak. Protein ikut pula mengatur berbagai proses tubuh, baik langsung maupun tidak langsung dengan membentuk zat-zat pengatur proses dalam tubuh. (8).

Uji korelasi antara asupan lemak dan status gizi sesuai dengan penelitian yang dilakukan oleh Oktaviani, bahwa terdapat hubungan yang signifikan antara asupan lemak dan statsu gizi dengan p:0.001. (9) Konsumsi lemak total sehari dianjurkan sebanyak 20$30 \%$ kecukupan energi sehari. Makanan tinggi lemak jenuh dan kolesterol berhubungan dengan meningkatnya kejadian penyakit jantung koroner. Selain itu, maknan lemak tinggi berkontribusi terhadap timbulnya obesitas dan meingkatnya risiko terhadap kanker (6)

Hasil penelitian ini sejalan dengan penelitian Ilham et al, menyatakan bahwa ada hubungan antara konsumsi karbohidrat dan Indeks Massa Tubuh dengan p:0.000. (10) Konsumsi karbohidrat dianjurkan antara 50-65\% dari kebutuhan energi total, terutama dalam bentuk karbohidrat kompleks seperti yang terdapat di dalam padipadian (beras, jagung, gandum dan hasil olahannya seperti roti), umbi-umbian (kentang, singkong, dan ubi), serta tepung-tepungan seperti tepung beras, tepung terigu, tepung sagu, dan tepung singkong. Karbohidrat kompleks merupakan sumber serat makanan. Serat makanan membantu melancarkan buang air besar dan dapat menurunkan kadar kolesterol darah. Proses pencernaan dan penyerapan karbohidrat kompleks dalam tubuh berlangsung lebih lamadibandingkan dengan karbohidrat sederhana seperti gula. Gula dapat langsung diserap dan digunakan tubuh 
sebagai sumber energi, sehingga cepat menimbulkan rasa lapar (6)

Hasil penelitian ini juga menunjukkan tidak ada hubungan antara aktivitas fisik dengan status gizi $(\mathrm{p}=$ 0.894). Hasil penelitian ini tidak sejalan dengan penelitian Aminin, yang menyatakan ada hubungan antara aktivitas fisik dengan status gizi (p:0.001).(11)

Aktivitas fisik merupakan upaya untuk menyeimbangkan antara pengeluaran dan asupan zat gizi terutama sumber energi dalam tubuh.

Aktivitas sisik juga memperlancar sistem metabolisme di dalam tubuh, termasuk metabolisme zat gizi. Oleh sebab itu, aktivitas fisik berfungsi dalam menyeimbangkan antara asupan gizi dan pengeluaran energi tubuh (Par'i, 2016). (2)

\section{SIMPULAN}

Berdasarkan hasil penelitian dan pembahasan, maka dapat disimpulkan bahwa terdapat hubungan yang siginifikan anatar asupan protein (p:0.042), asupan lemak (p:0.000) dan asupan karbohidrat (p:0.000) denagn status gizi. Tidak terdapat hubungan yang signifikan antara aktivitas fisik dengan status gizi (p:0.894).

\section{SARAN}

Perlu adanya edukasi tentang perilaku hidup sehat kepada seluruh pegawai Poltekkes Kemenkes Jakarta II. Perlu di fasilitasi sarana untuk mendukung perilaku hidup sehat seperti kantin sehat dan sarana olahraga. Mempertimbangkan variabel-variabel lain yang diduga berpengaruh terhadp status gizi.

\section{UCAPAN TERIMA KASIH}

Ucapan terima kasih kepada I Gunarti Y, DCN, MM, RD dan Edri Indah Yuliza Nur, M. yang telah memberikan saran untuk pembahasan pada artikel ini.

\section{DAFTAR PUSTAKA}

1. Kementerian Kesehatan RI. Riset Kesehatan Dasar Riskesdas 2013. Badan Penelitian Dan Pengembangan Kesehatan Kementerian Kesehatan Ri Tahun 2013

2. Par'i HM . Penilaian Status Gizi. Jakarta: Penerbit Buku Kedokteran EGC. 2016

3. Widiantini W. Aktivitas Fisik, Stres, dan Obesitas pada Pegawai Negeri Sipil. Pusat Data dan 
Informasi Sekjen Kemenetrian Kesehatan RI. Jakarta. 2013

4. Lathifah N. Perbedaan Kadar Glukosa Darah Orang Dewasa Dengan IMT Gemuk Serta Faktorfaktor yang Mempengaruhi Di Politeknik Kesehatan Jakarta II Kampus A [KTI]. Jakarta : Polteknik Kesehatan Jakarta II.2013

5. Darmawanti, RA. Hubungan Asupan Gizi dan Aktivitas Fisik dengna Status Gizi, Tekanan Darah dan Kadar Gula Darah Komunitas Pria Rutin Olahraga di Persatuan Bulutangkis Laksana Jakarta Timur [Skripsi]. Jakarta : STIKes Binawan. 2017

6. Almatsier et al. Gizi Seimbang Dalam Daur Kehidupan. Jakarta : PT Gramedia Pustaka Utama. 2011

7. Stephanie et al.. Hubungan Antara Asupan Zat Gizi Makro Dengan Obesitas Pada Wanita Usia Subur Peserta Jamkesmas Di Puskesmas Wawonasa Kecamatan Singkil Manado.Jurnal e-Biomedik (eBM)Volume 1, Nomor 1 :607613. 2013
8. Winarno FG. Kimia Pangan dan Gizi. Jakarta : Gramedia Pustaka Utama. 2002

9. Oktaviani, WD. Hubungan Kebiasaan Konsumsi Fast Food, Aktivitas Fisik, Pola Konsumsi, Karakteristik Remaja dan Orang Tua dengan Indeks Masa Tubuh [Thesis]. Semarang : Universitas Diponegoro. 2012

10. Ilham et al. Hubungan Asupan Energi dan Protein Terhadap Indeks Massa Tubuh Mahasiswa UIN Sunan Ampel Surabaya. Journal of Health Science and Prevention, Vol.1(2). 2017

11. Aminin F.. Hubungan Aktivitas Fisik dan Frekuensi Fast Food Dengan Kejadian Overweight Pada Remaja Di SMP N 5 Karanganyar [Skripsi].Surakarta : Universitas Muhammadiyah Surakarta. 2016 